Article

\title{
Exergoeconomic Assessment of a Compact Electricity-Cooling Cogeneration Unit
}

\author{
Adriano da S. Marques ${ }^{1}\left(\mathbb{D}\right.$, Monica Carvalho ${ }^{2, *} \mathbb{C}$, Álvaro A. V. Ochoa ${ }^{3}{ }^{(}$, Ronelly J. Souza ${ }^{4}$ \\ and Carlos A. C. dos Santos 4 \\ 1 Department of Mechanical Engineering, Federal Rural University of Pernambuco, Rua Cento e Sessenta e \\ Três, 300, Cabo de Santo Agostinho 54518-430, Brazil; adriano.marques@ufrpe.br \\ 2 Department of Renewable Energy Engineering, Federal University of Paraiba, Cidade Universitaria, s/n, \\ João Pessoa 58051-900, Brazil \\ 3 Academic Department of Industrial Control, Federal Institute of Technology of Pernambuco, \\ Av. Prof Luiz Freire, 500, Recife 50740-540, Brazil; ochoaalvaro@recife.ifpe.edu.br \\ 4 Department of Mechanical Engineering, Federal University of Paraiba, Cidade Universitaria, s/n, \\ João Pessoa/PB 58051-900, Brazil; ronelly84@gmail.com (R.J.S.); \\ carloscabralsantos@yahoo.com.br (C.A.C.d.S.) \\ * Correspondence: monica@cear.ufpb.br; Tel.: +55-83-3216-7268
}

Received: 1 September 2020; Accepted: 14 October 2020; Published: 16 October 2020

check for updates

\begin{abstract}
This study applies the SPecific Exergy COsting (SPECO) methodology for the exergoeconomic assessment of a compact electricity-cooling cogeneration system. The system utilizes the exhaust gases from a $126 \mathrm{hp}$ Otto-cycle internal combustion engine (ICE) to drive a $5 \mathrm{RT}$ ammonia-water absorption refrigeration unit. Exergy destruction is higher in the ICE $(67.88 \%)$, followed by the steam generator $(14.46 \%)$. Considering the cost of destroyed exergy plus total cost rate of equipment, the highest values are found in the ICE, followed by the steam generator. Analysis of relative cost differences and exergoeconomic factors indicate that improvements should focus on the steam generator, evaporator, and absorber. The cost rate of the fuel consumed by the combustion engine is $12.84 \mathrm{USD} / \mathrm{h}$, at a specific exergy cost of $25.76 \mathrm{USD} / \mathrm{GJ}$. The engine produces power at a cost rate of $10.52 \mathrm{USD} / \mathrm{h}$ and specific exergy cost of $64.14 \mathrm{USD} / \mathrm{GJ}$. Cooling refers to the chilled water from the evaporator at a cost rate of $0.85 \mathrm{USD} / \mathrm{h}$ and specific exergy cost of $84.74 \mathrm{USD} / \mathrm{GJ}$. This study expands the knowledge base regarding the exergoeconomic assessment of compact combined cooling and power systems.
\end{abstract}

Keywords: thermoeconomics; combined cooling and power; combustion engine; absorption refrigeration; SPECO

\section{Introduction}

Compact combined cooling and power systems, which couple a combustion engine or gas turbine to an absorption refrigeration system, are considered a suitable alternative to single-generation systems [1,2]. This arrangement can also be referred to as compact electricity-cooling cogeneration systems, and has been applied to industries [3,4], the tertiary sector [5-7] such as in supermarkets and shopping centers, and also to meet the domestic energy demands of residential buildings [8-13].

Absorption refrigeration presents several advantages when compared to traditional vapor compression refrigeration systems: utilization of low-quality heat (e.g., exhaust gases or from renewable sources such as solar [14]), low energy costs [15], no need for a compressor [16], and low levels of pollution as these systems do not employ halogens $[17,18]$. The global exergy efficiency is higher than vapor compression systems due to the utilization of waste heat [19], with consequent lower levels of losses and irreversibilities. Absorption refrigeration has become technically, economically, and even 
environmentally viable and has been the focus of several studies in different sectors [20-24]. Absorption refrigeration has also been part of optimization studies that synthesized energy systems from economic and environmental viewpoints [25-27], although it was not always present in the optimal solution.

Different perspectives can be applied to assess electricity-cooling compact cogeneration systems. Exergy analysis is fundamental to characterize the utilization and destruction of exergy in the various steps of the process $[28,29]$. As the irreversibilities can be pinpointed and quantified, equipment that could benefit from energy improvements can be identified [30-32]. Therefore, exergy analysis is crucial to complement energy analysis and the evaluation of thermal efficiency indicators.

Going a step further, exergoeconomics (exergy-aided cost-reduction method) combines exergy and cost analyses to provide information not available through separate conventional energy, exergy, or cost analyses. The results of exergoeconomic analyses can guide towards the cost-effective design and operation of energy systems. Marques et al. [33] reported a detailed exergoeconomic assessment for a micro-trigeneration system, while Sharifi and Khalilarya [34] focused on a combined power and absorption-ejector refrigeration cycle. Hou et al. [35] addressed a waste heat power generation project based on an Organic Rankine Cycle (ORC), and a novel ORC-based electricity-cooling cogeneration system was the focus of an exergoeconomic analysis and optimization by Kordlar and Mahmoudi [36].

Within this context, there is a clear need to carry out adequate and effective analyses to compare different thermal alternatives for the generation of cooling, including the utilization of waste heat from the exhaust gases of an engine or turbine [37,38]. The association of energy, exergy, and economic analyses is a rational path for studying energy systems, being a technical decision-making tool in energy projects. Some authors have applied exergy and exergoeconomic evaluations to energy systems, and recent studies have focused on a natural gas-proton-exchange membrane fuel cell [39], novel trigeneration systems using solid oxide fuel cell [40], biomass and solar energy, a combined cycle integrated with biomass gasification [41], a liquid carbon dioxide energy storage system [42], and even included environmental data in the assessment of an eucalyptus biomass-fired power plant [43]. The review presented by Wang et al. [44] advocates for the application of exergoeconomics to the evaluation, optimization, and synthesis of energy systems.

Among the different methodologies to perform exergoeconomic analysis, the SPECO (Specific Exergy Costing) method was developed by combining and improving two other methods: AVCO (Average Cost) and LIFO (Last in First out) [45]. SPECO-based exergoeconomic assessments have been carried out for different applications, such as the work of Mazloum et al. [46], who present a proposal for the utilization of exergoeconomic parameters in the optimization of an adiabatic compression system. Kerdan et al. [47] developed an exergoeconomic-based parametric study to examine the effects of active and passive energy retrofit strategies for buildings. Fathia et al. [48] carried out a SPECO-based optimization for the equipment of a desalination unit used in an industrial steam production plant in Tunisia, and Mahmoudi et al. [49] optimized the heat exchangers of a single-effect $\mathrm{LiBr}-\mathrm{H}_{2} \mathrm{O}$ absorption refrigeration system. Among different cogeneration systems, those producing cooling and power have been the focus of more recent investigations, mainly when low-grade heat is employed as a heat source [50-58].

To the best of the authors' knowledge and after systematic reviews, a compact electricity-cooling cogeneration system has not been the focus of any SPECO-based exergoeconomic assessment, which is precisely the knowledge gap we aim to fill. Besides providing exergoeconomic results for this niche application, the study makes a case for the adoption of co- and tri-generation systems. The objective of this study is to develop an exergoeconomic assessment, employing the SPECO methodology for a stationary cogeneration unit. The system is constituted by an Otto-cycle internal combustion engine and a water-ammonia single-effect absorption chiller. The contribution is to provide a detailed guide for the application of the exergoeconomic assessment, promote the dissemination of compact electricity-cooling cogeneration systems (unique application), and provide results to be compared with other (future) studies. A step-by-step, clear, and straightforward guide to the application of 
exergy-based methods is presented herein, with sufficient information to guarantee reproducibility and replicability.

\section{Case Study: Description of the Compact Cogeneration Unit}

The cogeneration module analyzed herein is proposed to attend industrial processes, supplying cooling and electricity. The module is constituted by an internal combustion engine (ICE, Otto cycle), maximum engine power is $126 \mathrm{hp}(92.67 \mathrm{~kW})$ at $5250 \mathrm{rpm}$, driven by gasoline, and by a single-effect absorption refrigeration system, $5 \mathrm{RT}(17.58 \mathrm{~kW})$ cooling capacity, which employs the pair ammonia-water $\left(\mathrm{NH}_{3} / \mathrm{H}_{2} \mathrm{O}\right)$ as refrigerant and absorbent fluids. The refrigeration system is based on a ROBUR-SERVER equipment (model ACF-60), which includes a steam generator with a steam rectifier, a condenser, an absorber, one evaporator, an intermediate heat exchanger, a pump, and two expansion valves. Figure 1 presents the operation scheme of the cogeneration unit.

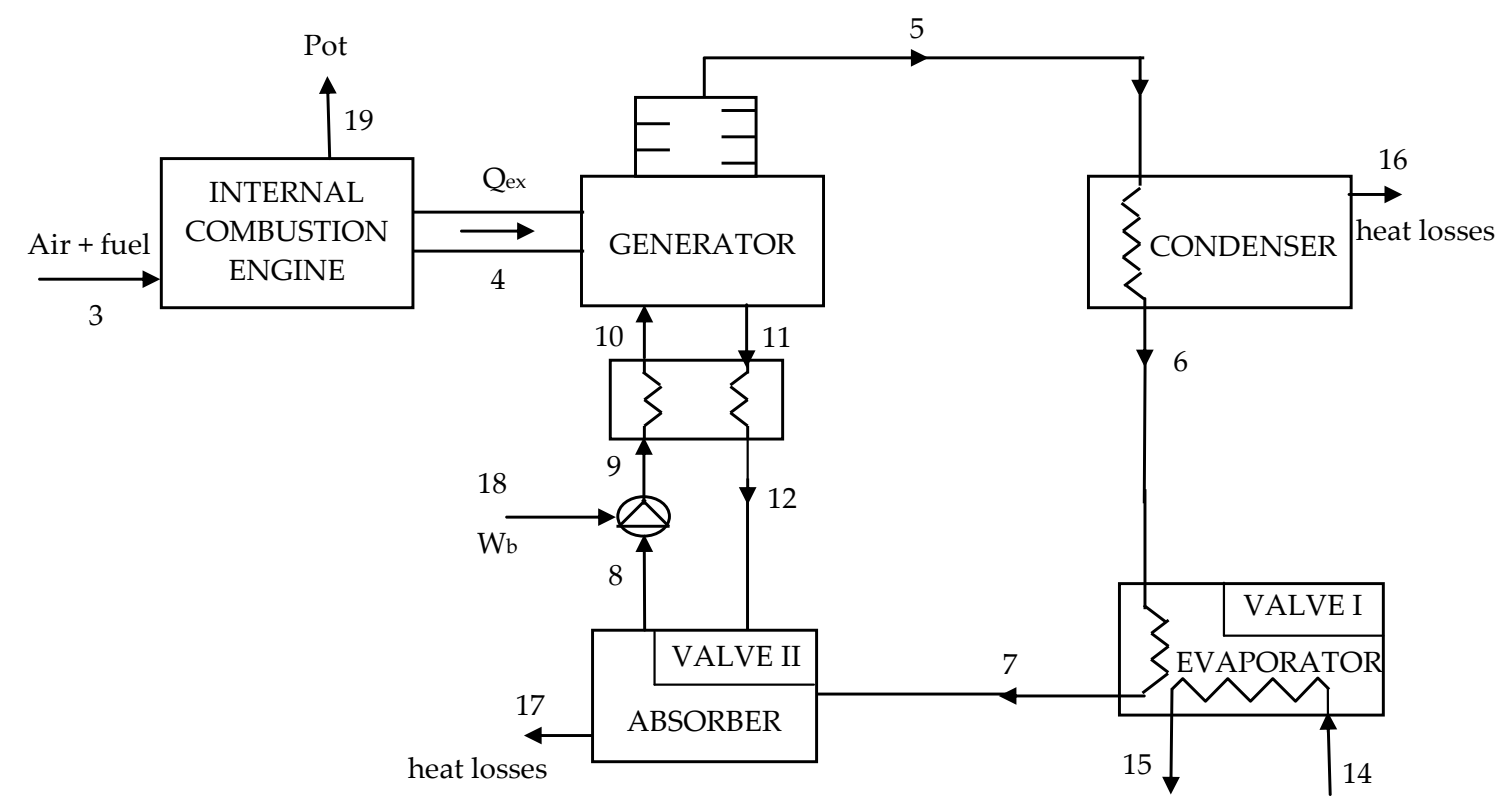

Figure 1. Scheme of the compact cogeneration module.

The ICE receives the air + fuel mixture, produces mechanical work, and rejects exhaust gases from the combustion process via exhaustion pipes. Due to the high temperature of these exhaust gases, heat can be harnessed and utilized by the steam generator of the refrigeration system, which contains the ammonia-water mixture. This mixture is heated until ebullition, generating high-pressure vapor that flows through the steam rectifier. This device is employed to guarantee that only highly concentrated ammonia vapor (approximately 99.8\%) reaches the condenser. When this vapor enters in contact with the fins of the equipment, the water condenses, and only ammonia vapor (less dense) flows to the condenser. The condensed water returns to the steam generator, diluting the ammonia solution inside. The highly concentrated ammonia solution that exits the rectifier is cooled in the condenser, transferring heat to ambient air, and changes to the liquid phase. This fluid flows through an expansion valve and has its pressure abruptly decreased, causing an unbalance of pressures within the system and, consequently, the cooling effect is produced in the evaporator. In the evaporator, the ammonia solution suffers evaporation due to heat transfer from water. The absorber contains the weak ammonia solution (and therefore more water), which immediately absorbs the vaporized ammonia in the evaporator due to the high chemical affinity between these two elements. Part of the solution contained in the absorber flows to the steam generator, with the help of a hydraulic pump (which consumes electricity). When the solution flows from the absorber to the steam generator, it is pre-heated in the intermediate heat exchanger by the weak solution from the generator. This increases the efficiency of the cycle 
because it requires lower temperatures from the exhaust gases. The weak ammonia solution that exits the generator and enters the absorber flows through an expansion valve to maintain thermal balance and system pressure, closing the cycle and ensuring the correct operation of the system.

All analyses were performed individually for each equipment of the proposed unit. This means that each piece of equipment was analyzed as a control volume, except for the valves, which were incorporated into the subsequent equipment.

\section{Thermodynamic Model}

The following assumptions are invoked during modeling, following Reference [29]:

- Steady state,

- Effects of kinetic and potential energy were not considered,

- Isoentalpic expansions were considered for the expansion valves,

- Pressure drops were considered negligible within the overall system,

- Compression and expansion processes were considered adiabatic,

- All processes were internally reversible,

- Combustion air and exhaust gases were considered as ideal gas mixtures,

- Complete combustion was considered for gasoline.

The thermodynamic analysis was divided into two steps: (i) internal combustion engine, and (ii) each component of the absorption refrigeration system. A computational code was built in the Engineering Equation Solver [59] to carry out the thermodynamic and exergoeconomic balances.

Internal Combustion Engine:

The cogeneration module engine is an I4 Ford, 16 valves, internal cylinder bore $87.5 \mathrm{~mm}$, piston stroke $83.1 \mathrm{~mm}$, four cylinders, and compression rate 10:1. The combustion process was simulated using fuel composition as the input parameter.

The stoichiometric balance for the combustion is given by Equation (1):

$$
\mathrm{C}_{8} \mathrm{H}_{18}+\operatorname{exc} \times \mathrm{a} \cdot\left(\mathrm{O}_{2}+3.76 \mathrm{~N}_{2}\right) \rightarrow \mathrm{b} \cdot \mathrm{CO}_{2}+\mathrm{c} \cdot \mathrm{H}_{2} \mathrm{O}+\mathrm{d} \cdot \mathrm{N}_{2}+\mathrm{e} \cdot \mathrm{O}_{2}
$$

where "exc" represents the excess air of combustion, and the terms " $a$ ", " $b$ ", "c", " $d$ ", and "e" are the parameters that balance out the equation. $\mathrm{C}_{8} \mathrm{H}_{18}, \mathrm{O}_{2}, \mathrm{~N}_{2}, \mathrm{CO}_{2}$, and $\mathrm{H}_{2} \mathrm{O}$ refer to gasoline, oxygen, nitrogen, carbon dioxide, and water, respectively. The air-fuel ratio was then determined, followed by determination of the air-fuel combustion energy.

The solution of the energy balance in the engine provided the energy contained in exhaust gases and the exergy associated with combustion products.

Absorption Refrigeration System:

The following physical-chemical characteristics were considered for the refrigeration system [60]: condenser temperature is ambient temperature plus $10^{\circ} \mathrm{C}$, evaporator temperature is $5^{\circ} \mathrm{C}$, refrigerant concentration at the steam rectifier is 0.999634 , concentrations of strong and weak ammonia solutions are, respectively, 0.368 and 0.268 .

The thermodynamic analysis begins with the application of mass conservation for each control volume. Then, the First Law of Thermodynamics was applied to obtain energy flows at inlets and outlets of each equipment as well as energy efficiency values. Mass and energy balances are straightforward and therefore not presented herein. Entropy balances followed to determine entropy generation at each equipment. The thermodynamic study also includes the determination of exergy flows at inlets and outlets of each equipment, as these values are fundamental for the development of exergoeconomic evaluations. 


\section{Economic Model}

The capital costs of the ICE and absorption refrigeration system were USD 386.85 and USD 348.16 respectively, as per purchase receipts (1 USD @ 5.17 BRL, Brazilian currency). The interest rate was assumed to be $5 \%$, and a 10 -year lifetime was considered.

The capital cost of the absorption refrigeration unit was divided into its internal components, according to their importance to the unit, as depicted in Table 1.

Table 1. Allocation of capital costs to each subsystem of the absorption refrigeration unit.

\begin{tabular}{cc}
\hline Subsystem & Factor (\%) \\
\hline Generator & 25 \\
Absorber & 25 \\
Evaporator & 20 \\
Condenser & 14 \\
Regenerator & 14 \\
Pump & 2 \\
\hline
\end{tabular}

The monetary cost of each piece of equipment $(\dot{Z})$ is determined by Equation (2) [61]:

$$
\dot{\mathrm{Z}}=\frac{(\mathrm{A} / \mathrm{P})}{\mathrm{t}_{\mathrm{op}}} \cdot \mathrm{F}_{\mathrm{i}}
$$

where " $\mathrm{A} / \mathrm{P}$ " is the capital recovery factor, " $\mathrm{F}_{\mathrm{i}}$ " represents the capital costs associated with each piece of equipment within the unit, and " $\mathrm{top}_{\mathrm{op}}$ " is the lifetime of the equipment.

The capital recovery factor took into account the interest rate $(i)$ and the total lifetime of the equipment (n) [62], as expressed by Equation (3):

$$
\frac{A}{P}=\left[\frac{i(1+i)^{n}}{(1+i)^{n}-1}\right]
$$

The cost rate of fuel is determined by Equation (4):

$$
\dot{C}_{c o m b}=\frac{\dot{m}_{\text {comb }}}{\rho_{\text {comb }}} \cdot \text { Tariff }_{\text {comb }} \cdot 1000
$$

No costs were associated with the consumption of electricity because a DC battery is used for this purpose. No cost was associated with the water inlet to the evaporator, as it is a closed water recirculation system. In this model, it is important to emphasize that the valves are incorporated into the following equipment (no differences between the entry and exit costs).

\section{Exergoeconomics: Application of the SPECO Method}

As mentioned earlier, there are different exergoeconomic methods employed in studies that combine monetary values and exergy flows. The SPECO method [45] is constituted by three steps: (i) determination of the exergy flows for each point of the system, (ii) definition of fuel and product for each energy flow within each control volume, considering the desired result (produced) by each piece of equipment and the resource consumed for such, and (iii) utilization of auxiliary equations that associate the cost of a thermal system with the environment and its irreversibilities.

Lazzaretto and Tsatsaronis [45] define the product as being all exergy flows that leave a component, plus all exergy increases between inlet and outlet that are in accordance with the function of the component. Fuel is defined as all exergy flows that enter a component, plus all the exergy decreases between inlet and outlet minus all the exergy increases (between inlet and outlet) that are not in accordance with the function of the component. 
Auxiliary equations are established based on the Fuel $(\mathrm{F})$ and Product $(\mathrm{P})$ principles, being an important characteristic of the SPECO method.

The F principle refers to the removal of exergy from a current within a given component, when for this current, the difference in exergy between input and output is considered in the definition of fuel. The specific cost associated with this removal of exergy must be equal to the average specific cost in which the removed exergy was supplied to the same current of the upstream component. In this way, an auxiliary equation is obtained for each removal of exergy, so the number of auxiliary equations provided by the F principle is always equal to the number of exergy flows from the fuel.

The P principle refers to the supply of exergy to an exergy flow within a component. Each unit of exergy is supplied to any current associated with the product at the same average cost $\left(c_{p}\right)$. As each flow to which exergy is supplied corresponds to an existing flow, the number of auxiliary equations provided by the $P$ principle is always equal to the number of outflow exergy that are included in the product definition. Thus, principles $\mathrm{F}$ and $\mathrm{P}$ together provide the number of auxiliary equations needed.

SPECO $[45,63,64]$ utilizes the exergy of inlet and outlet flows, monetary tariffs for each input, exergy efficiency, and auxiliary equations. The first step is to apply the exergy cost balance for each equipment:

$$
\sum_{\mathrm{e}}\left(\mathrm{c}_{\mathrm{e}} \cdot \mathrm{Ex}_{\mathrm{e}}\right)_{\mathrm{k}}+\left(\mathrm{c}_{\mathrm{w}} \cdot \dot{\mathrm{W}}\right)=\mathrm{c}_{\mathrm{q}} \cdot \mathrm{Ex}_{\mathrm{q}}+\sum_{\mathrm{i}}\left(\mathrm{c}_{\mathrm{i}} \cdot \mathrm{Ex}_{\mathrm{i}}\right)_{\mathrm{k}}+\dot{\mathrm{Z}}_{\mathrm{k}}
$$

where " $c$ " represents the specific monetary cost, "W ." is the power of the equipment, $\mathrm{Ex}_{\mathrm{q}}$ is the exergy associated with heat flows, " $\mathrm{Z}$ " is the total cost rate of equipment, and " $\mathrm{e}$ " and " $\mathrm{i}$ " refer, respectively, to the outputs and inputs of each analyzed control volume.

The total cost rate of equipment is constituted by the capital cost rate $\left(\dot{Z}^{C I}\right)$ and the operation and maintenance cost rate $\left(\dot{\mathrm{Z}}^{\mathrm{OM}}\right)$ :

$$
\dot{\mathrm{Z}}=\dot{\mathrm{Z}}^{\mathrm{CI}}+\dot{\mathrm{Z}}^{\mathrm{OM}}
$$

The exergy efficiency of each equipment $(\varepsilon)$ can be determined by the relationship between the exergy of the products $\left(\mathrm{Ex}_{\mathrm{P}}\right)$ and the exergy of the fuels $\left(\mathrm{Ex}_{\mathrm{F}}\right)$ :

$$
\varepsilon=\frac{\mathrm{Ex}_{\mathrm{P}}}{\mathrm{Ex}_{\mathrm{F}}}
$$

The difference between the exergy of the fuels and products represents the rate of exergy destruction in each equipment $\left(\mathrm{Ex}_{\mathrm{D}}\right)$ :

$$
\mathrm{Ex}_{\mathrm{D}}=\mathrm{Ex}_{\mathrm{F}}-\mathrm{Ex}_{\mathrm{P}}
$$

The product of the specific cost of fuels $\left(c_{f}\right)$ by the exergy destroyed in the equipment $\left(\operatorname{Ex}_{\mathrm{D}}\right)$ is the cost of the exergy destroyed $\left(\dot{\mathrm{C}}_{\mathrm{D}}\right)$ :

$$
\dot{\mathrm{C}}_{\mathrm{D}}=\mathrm{c}_{\mathrm{f}} \cdot \mathrm{Ex}_{\mathrm{D}}
$$

In SPECO, the cost of adding exergy to a flow is determined and charged to the unit that makes use of that exergy, i.e., a component can obtain the exergy from a flow at different costs, depending on the components that supplied the exergy [65]. In other words, SPECO provides a price rate to every exergy component of each flow entering and exiting the components.

The relative cost difference, $\mathrm{r}_{\mathrm{k}}$, indicates the relative increase in the average cost per exergy unit between the fuel $\left(c_{\mathrm{f}}\right)$ and the product $\left(\mathrm{c}_{\mathrm{p}}\right)$ :

$$
\mathrm{r}_{\mathrm{k}}=\frac{\mathrm{c}_{\mathrm{P}}-\mathrm{c}_{\mathrm{f}}}{\mathrm{c}_{\mathrm{f}}}
$$

Exergy destruction and capital costs have the highest impacts on the relative cost difference. Manesh et al. [66] mentioned that special attention should be directed to components with a high relative 
cost difference, especially when the cost rates associated with capital costs and exergy destruction are high.

The exergoeconomic factor $\left(f_{k}\right)$ is another relevant parameter when evaluating exergy costs with the SPECO method, indicating the viability of investment in each component:

$$
\mathrm{f}_{\mathrm{k}}=\frac{\dot{\mathrm{Z}}}{\mathrm{c}_{\mathrm{f}} \cdot \mathrm{Ex}_{\mathrm{D}}+\dot{\mathrm{Z}}}
$$

The exergoeconomic factor compares the capital costs with the cost rate of exergy destruction in a specific piece of equipment. Low $\mathrm{f}_{\mathrm{k}}$ values indicate that the costs associated with irreversibilities are significant compared to the capital cost of the equipment. This situation can be minimized by decreasing irreversibilities in the equipment.

Table 2 presents the exergoeconomic balances for each equipment, as well as the auxiliary equations employed.

Table 2. Exergoeconomic balances (Specific Exergy Costing, SPECO) for each equipment of the system.

\begin{tabular}{cccc}
\hline Equipment & Product & Fuel & Auxiliary Equation \\
\hline Internal combustion engine & $c_{19} \cdot \dot{E} x_{19}$ & $c_{3} \cdot \dot{E} x_{3}-c_{4} \cdot \dot{E} x_{4}$ & $c_{4}=c_{3}$ \\
Steam generator & $c_{5} \cdot \dot{E} x_{5}+\left(c_{11} \cdot \dot{E} x_{11}-c_{10} \cdot \dot{E} x_{10}\right)$ & $c_{4} \cdot \dot{E} x_{4}$ & $c_{5}=\frac{\dot{C}_{11}-\dot{C}_{10}}{\dot{E} x_{11}-\dot{E} x_{10}}$ \\
Condenser + valve & $c_{16} \cdot \dot{E} x_{16}$ & $c_{5} \cdot \dot{E} x_{5}-c_{6} \cdot \dot{E} x_{6}$ & $c_{6}=c_{5}$ \\
Evaporator & $c_{15} \cdot \dot{E} x_{15}-c_{14} \cdot \dot{E} x_{14}$ & $c_{6} \cdot \dot{E} x_{6}-c_{7} \cdot \dot{E} x_{7}$ & $c_{7}=c_{6}$ \\
Absorber + valve & $c_{17} \cdot \dot{E} x_{17}$ & $c_{12} \cdot \dot{E} x_{12}+\left(c_{7} \cdot \dot{E} x_{7}-c_{8} \cdot \dot{E} x_{8}\right)$ & $c_{12}=\frac{\dot{C}_{7}-\dot{C}_{8}}{\dot{E x}-\dot{E} x_{8}}$ \\
Pump & $c_{9} \cdot \dot{E} x_{9}-c_{8} \cdot \dot{E} x_{8}$ & $c_{18} \cdot \dot{E} x_{18}$ & Not applicable \\
Intermediate heat exchanger & $c_{10} \cdot \dot{E} x_{10}-c_{9} \cdot \dot{E} x_{9}$ & $c_{11} \cdot \dot{E} x_{11}-c_{12} \cdot \dot{E} x_{12}$ & $c_{12}=c_{11}$ \\
\hline
\end{tabular}

\section{Results and Discussion}

This section presents the results of the thermodynamic and exergoeconomic assessments for the compact cogeneration unit.

\subsection{Thermodynamic Results}

All thermodynamic states were determined for the points indicated in Figure 1. These points represent the inlet and outlet conditions for each equipment within the system studied herein. Table 3 presents the results of the thermodynamic analysis.

Table 3. Thermodynamic assessment results.

\begin{tabular}{ccccccc}
\hline$\#$ & Flows & $\begin{array}{c}\dot{\mathbf{m}} \\
\mathbf{( k g} / \mathbf{s})\end{array}$ & $\begin{array}{c}\mathbf{T} \\
\left({ }^{\circ} \mathbf{C}\right)\end{array}$ & $\begin{array}{c}\mathbf{P} \\
\mathbf{( b a r )}\end{array}$ & $\begin{array}{c}\mathbf{H} \\
\mathbf{( k J / k g )}\end{array}$ & $\begin{array}{c}\mathbf{S} \\
\mathbf{( k J / k g} \cdot \mathbf{K})\end{array}$ \\
\hline 3 & Fuel & 0.0035 & 25.0 & 1.00 & - & - \\
4 & Exhaust gases & 0.0525 & 680.5 & 3.20 & - & - \\
5 & Refrigerant & 0.0219 & 39.9 & 13.51 & 1297.00 & 4.24 \\
6 & Refrigerant & 0.0219 & -12.5 & 2.63 & 166.00 & 0.65 \\
7 & Refrigerant & 0.0219 & 5.0 & 2.63 & 1296.00 & 4.97 \\
8 & Strong solution & 0.1599 & 42.6 & 2.63 & -30.81 & 0.51 \\
9 & Strong solution & 0.1599 & 44.9 & 13.51 & -20.27 & 0.54 \\
10 & Strong solution & 0.1599 & 96.5 & 13.51 & 210.10 & 1.21 \\
11 & Weak solution & 0.1380 & 124.3 & 13.51 & 369.60 & 1.57 \\
12 & Weak solution & 0.1380 & 62.8 & 2.63 & 102.70 & 0.85 \\
14 & Inlet water & 1.1800 & 12.0 & - & 50.51 & 0.18 \\
15 & Outlet water & 1.1800 & 7.0 & - & 29.53 & 0.11 \\
\hline
\end{tabular}


Table 3 shows that the highest temperature is found in the ICE exhaust gases, as expected (point \#4). The high- and low-pressure levels of the refrigeration system can be seen when comparing the pressures of points 5-12 (2.63 bar and $13.51 \mathrm{bar}$ ).

It must be highlighted that temperature at \#4 is extremely high—the heat of exhaust gases can be employed to drive an absorption chiller. A waste heat recovery scheme for a submarine was proposed in Reference [67] to harness heat from exhaust gases and cooling jacket water and drive a mixed effect absorption chiller. Following the same concept, exhaust gases from a natural gas engine were used in a recovery boiler in Reference [68], producing steam and hot water. The latter was used to drive an absorption chiller in a trigeneration system that met the energy demands of an ice cream factory. Nevertheless, excess heat could also be used to heat a secondary fluid (water or oil, for example) for another process. Waste heat recovery can speed up the warming of lubricant oil, with a significant reduction of fuel consumption and pollutant emissions experimentally demonstrated in Reference [69]. Different waste heat recovery schemes for natural gas engines were presented by Reference [70], based on an ORC coupled with a thermal oil circuit. Reference [71] used natural gas to fuel an ORC + absorption chiller scheme, producing electricity, heat, and chilled water to satisfy the demands of a university building. Other waste heat recovery options have been reported by Reference [72], which encompass direct uses (radiation/convection recuperator, passive air preheater, waste heat boiler, economizer, plate heat exchanger, to name a few) and indirect uses (heat-to-heat conversion, heat-to-cooling conversion, and heat-to-power conversion). The enthalpy and entropy values obtained herein are in accordance with scientific literature values for absorption-based refrigeration systems [73-76].

\subsection{Exergoeconomic Results}

Table 4 shows the results of the exergoeconomic evaluation via the SPECO method. The tariff considered for gasoline was USD 0.72/1.

Table 4. Results of exergy costs: SPECO method.

\begin{tabular}{cccccc}
\hline$\#$ & Flows & $\begin{array}{c}\mathbf{e x} \\
\mathbf{( k J / k g )}\end{array}$ & $\dot{\boldsymbol{E}}_{\boldsymbol{x}}(\mathbf{k W})$ & $\begin{array}{c}\dot{\mathbf{C}} \\
\mathbf{( U S D} / \mathbf{h})\end{array}$ & $\begin{array}{c}\mathbf{c} \\
\mathbf{( U S D / G J )}\end{array}$ \\
\hline 3 & Fuel & 39790 & 138.51 & 12.84 & 25.76 \\
4 & ICE ${ }^{*}$ gases & 7205 & 25.08 & 2.32 & 25.76 \\
5 & Refrigerant & 354.20 & 7.76 & 1.70 & 60.83 \\
6 & Refrigerant & 314.00 & 6.88 & 1.51 & 60.83 \\
7 & Refrigerant & 135.80 & 2.98 & 0.65 & 60.83 \\
8 & Strong solution & 3.29 & 0.53 & 0.12 & 63.48 \\
9 & Strong solution & 5.05 & 0.81 & 0.12 & 41.53 \\
10 & Strong solution & 35.41 & 5.66 & 2.06 & 101.32 \\
11 & Weak solution & 61.75 & 8.52 & 2.69 & 87.72 \\
12 & Weak solution & 10.51 & 1.60 & 0.51 & 87.72 \\
14 & Inlet water & 1.22 & 1.44 & 0.00 & 0.00 \\
15 & Outlet water & 2.37 & 2.80 & 0.85 & 84.74 \\
16 & Condenser heat & - & 0.80 & 0.19 & 66.94 \\
17 & Absorber heat & - & 1.81 & 1.28 & 196.32 \\
18 & Electricity: pump & - & 1.69 & 0.00 & 0.00 \\
19 & ICE ${ }^{*}$ power & - & 45.55 & 10.52 & 64.14 \\
\hline
\end{tabular}

* Internal Combustion Engine.

As expected, the highest costs are associated with the entry of air and fuel at the unit (\#3). The inlet and outlet flows of the steam generator (\#10,\#11) present high costs when compared with other flows of the refrigeration unit. The monetary costs associated with electricity and cooling are, respectively, 64.14 USD/GJ and $84.74 \mathrm{USD} / \mathrm{GJ}$. 
The specific exergy cost is presented in the far-right column of Table 4. The heat transfer at the absorber (\#17) presents the highest exergy cost, followed by the inlet of strong solution in the generator (\#10). Two essential processes in the absorber can explain this behavior (higher exergy costs): heat transfer between the cooling stream and the ammonia-water solution, and mass transfer between ammonia vapor and water, which releases a high amount of energy (with an exergy cost). The strong ammonia-water solution also presents a high energy potential, which also contributes to increasing the exergy cost of this current.

Table 5 presents more results of the exergoeconomic assessment: exergy destroyed $\left(\dot{E} x_{D}\right)$, cost rate of equipment $\left(\dot{Z}_{K}\right)$, exergy efficiency $(\varepsilon)$, relative cost difference $\left(\mathrm{r}_{\mathrm{k}}\right)$, and exergoeconomic factor $\left(\mathrm{f}_{\mathrm{k}}\right)$.

Table 5. Exergoeconomic parameters.

\begin{tabular}{cccccc}
\hline Equipment & $\dot{\mathbf{E}} \boldsymbol{x}_{\boldsymbol{D}}(\mathbf{k W})$ & $\dot{\mathbf{Z}}_{\boldsymbol{K}}(\mathbf{U S D} /$ Year $)$ & $\begin{array}{c}\boldsymbol{\varepsilon} \\
\mathbf{( \% )}\end{array}$ & $\begin{array}{c}\mathbf{r}_{\mathbf{k}} \\
\mathbf{( \% )}\end{array}$ & $\begin{array}{c}\mathbf{f}_{\mathbf{k}} \\
\mathbf{( \% )}\end{array}$ \\
\hline Internal combustion engine & 67.88 & 5.01 & 40.16 & 149.00 & 0.0091 \\
Steam generator & 14.46 & 1.13 & 42.34 & 136.20 & 0.0096 \\
Condenser & 0.08 & 0.63 & 90.91 & 10.04 & 0.4092 \\
Evaporator & 2.54 & 0.90 & 34.87 & 186.80 & 0.0185 \\
Absorber & 2.24 & 1.13 & 44.69 & 123.80 & 0.0182 \\
Pump & 1.41 & 0.09 & 16.57 & 0.00 & 100 \\
Intermediate heat exchanger & 2.07 & 0.63 & 70.09 & 42.69 & 0.0110 \\
\hline
\end{tabular}

The first column of Table 5 presents the destruction of exergy in each equipment. The highest exergy destruction occurs in the ICE, followed by the steam generator. The exergy destruction of the absorption refrigeration system is relatively small due to the low flow rate of the working fluid. Regarding the high destructions of exergy, the ICE and steam generator could benefit from reducing their heat losses. Higher efficiency heat exchangers could be employed to improve this situation and system performance. The highest exergy destruction rates and costs also occurred in the engine studied by Reference [77], but as mentioned by References [78,79], are inherent to the combustion process. Reference [80] investigated the factors affecting exergy destruction and identified that the most sensitive parameters for ICE were the thermodynamic state before combustion and the fuel employed.

Figure 2 depicts the costs associated with exergy destruction $\left(\dot{\mathrm{C}}_{\mathrm{D}}\right)$.

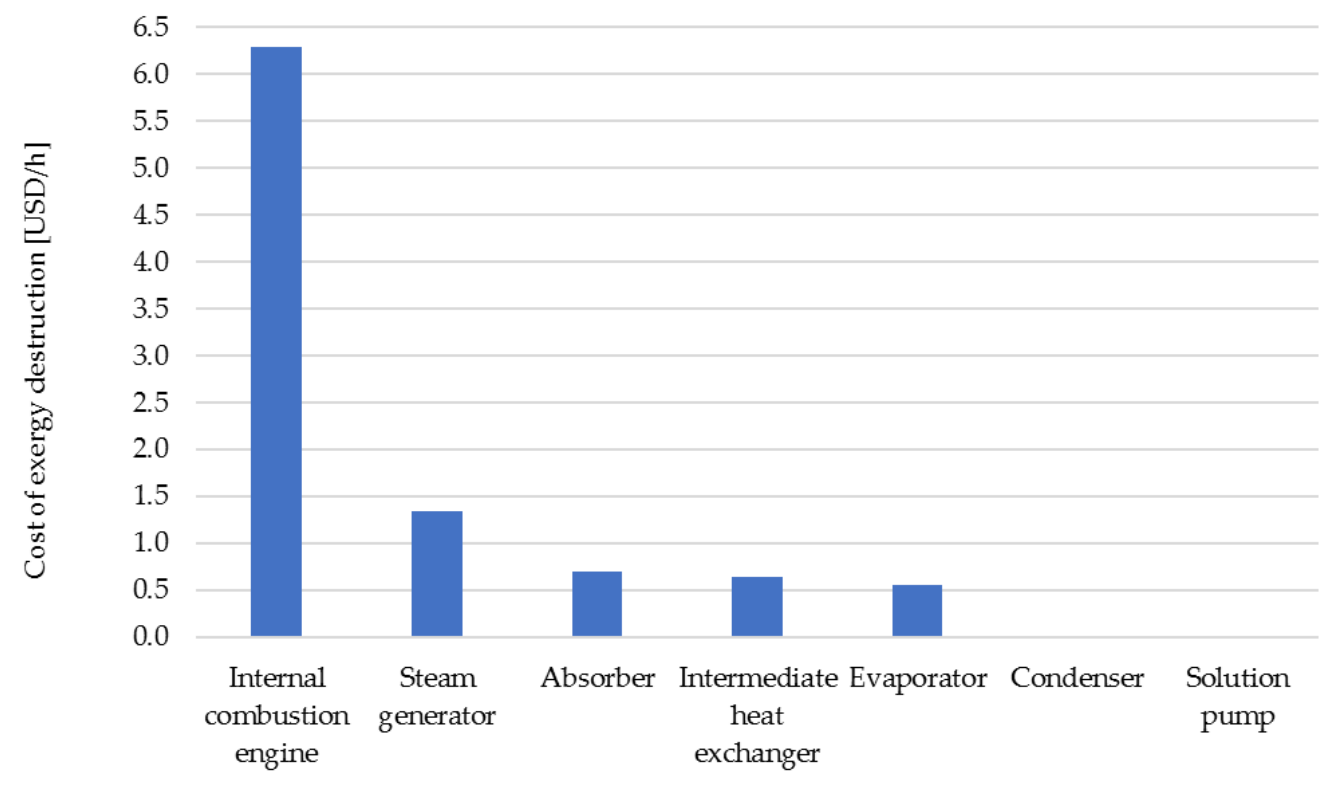

Equipment

Figure 2. Costs associated with the destruction of exergy, in USD/h. 
The second column of Table $5\left(\dot{Z}_{\mathrm{K}}\right)$ accounts for capital costs, operation, and maintenance of equipment, which are the inputs of the simulation. The highest costs are associated with the ICE, followed by the steam generator. Regarding the costs related to destroyed exergy $\left(\dot{C}_{D}\right)$, shown in Figure 2, again, the ICE presents the highest value, followed by the steam generator. When considering the combination of $\dot{C}_{D}+\dot{Z}_{k}$ (cost of destroyed exergy plus total cost rate of equipment), the highest value is associated with the ICE, which indicates the higher fraction of the total cost of the system. The second-highest value of $\dot{C}_{D}+\dot{Z}_{k}$ was for the steam generator. The other components have low values for $\dot{C}_{D}+\dot{Z}_{k}$, which indicates that improvements should focus elsewhere. The same conclusions were obtained by Shokati et al. [81,82]. As mentioned by Reference [33], such a level of knowledge on the cost-benefit assessment of improvements is provided by exergoeconomics only.

Table 5 shows that the condenser of the absorption system presents the highest exergy efficiency (ع) $(90.91 \%)$, followed by the intermediate heat exchanger of the refrigeration unit $(70.09 \%)$. The pump presents the lowest exergy efficiency, followed by the evaporator and then the ICE. Table 5 also presents two essential parameters for the exergoeconomic evaluation: the relative cost difference $\left(\mathrm{r}_{\mathrm{k}}\right)$ and the exergoeconomic factor $\left(f_{k}\right)$ of each component. Figure 3 shows the graphic relationship between $r_{k}$ and $f_{k}$ for each piece of equipment. For visualization purposes, Figure 3 shows $r_{k} / 10^{2}$ and $f_{k} / 10^{5}$.

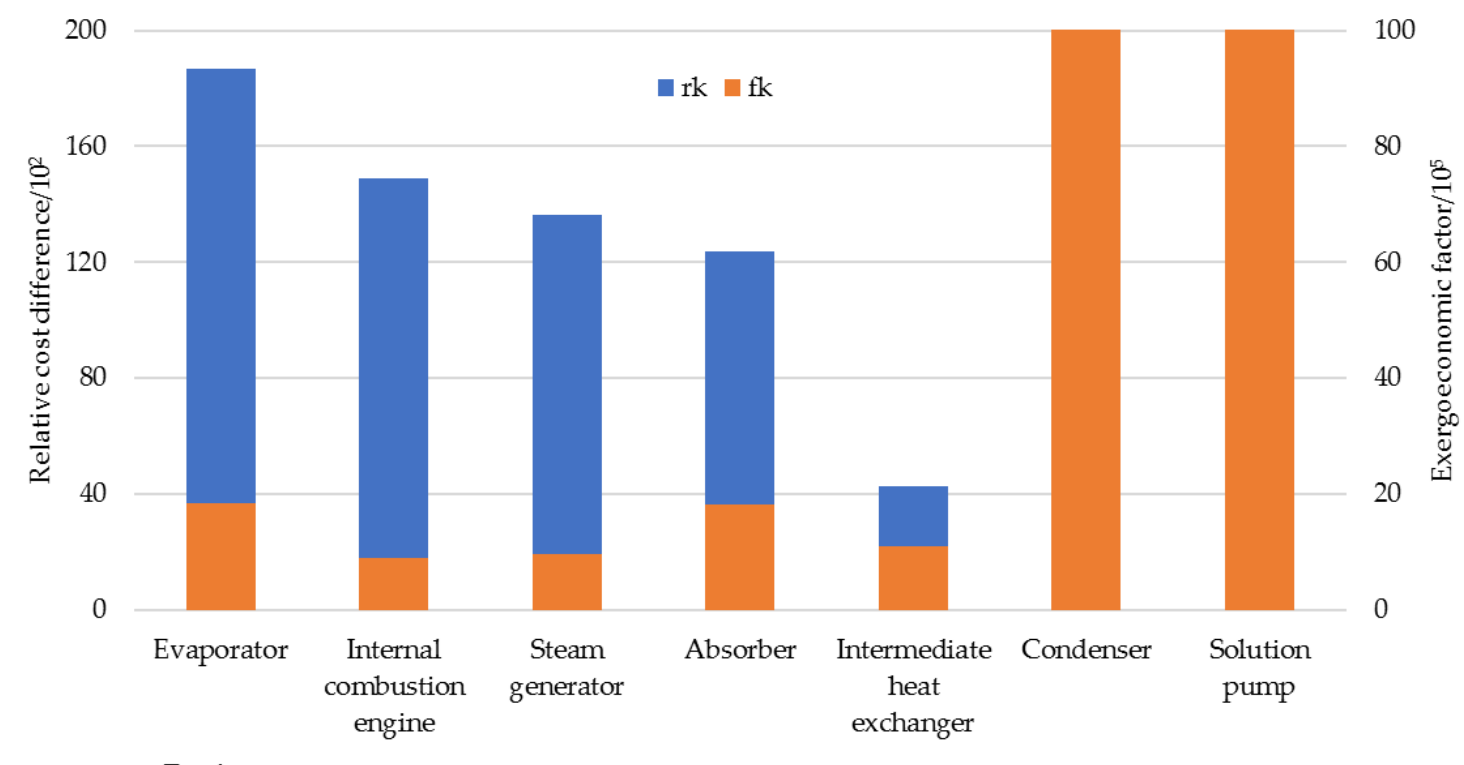

Equipment

Figure 3. Relative cost difference $\left(\mathrm{r}_{\mathrm{k}} / 10^{2}\right)$ and exergoeconomic factor $\left(\mathrm{f}_{\mathrm{k}} / 10^{5}\right)$ for each piece of equipment.

In Figure 3, attention should focus on the combination of high values for the blue columns and low values for orange columns (high $\mathrm{r}_{\mathrm{k}}$ and low $\mathrm{f}_{\mathrm{k}}$ ), which will indicate the optimization priorities. This combined analysis of $r_{k}$ and $f_{k}$ shows where optimization efforts should focus: steam generator, evaporator, and absorber. The values obtained for the ICE indicate that there are margins for improvement; however, this piece of equipment is commercially available and mass-produced, preventing interventions, and therefore, substituting the engine for another with higher efficiency has limited applicability. This approach was also followed by the authors of Reference [33], who identified that the absorber heat exchanger, steam generator, and heat recovery unit could benefit from improvements.

Cavalcanti [83] applied the same methodology to an integrated solar combined gas/steam cycle system and verified that the condenser presented the lowest exergoeconomic factor. In Cavalcanti et al. [84], a cogeneration system producing steam and electricity was analyzed, for which the lowest exergoeconomic factor was found for the combustor. These low $\mathrm{f}_{\mathrm{k}}$ values indicate the importance of decreasing irreversibilities in the equipment. Wu et al. [85] studied a combined supercritical $\mathrm{CO}_{2}$ recompression Brayton/absorption refrigeration cycle and obtained high $\mathrm{f}_{\mathrm{k}}$ values for the reactor and turbine, indicating that a decrease 
in their capital costs could be obtained at the expense of their efficiency. Rashidi and Yoo [86] studied power-cooling cogeneration systems and verified that optimization efforts for the Kalina-based system should focus on the absorber (highest $r_{k}$ and lowest $f_{k}$ ) and then on the superheater.

Shokati et al. [81] analyzed an ammonia-water double effect absorption refrigeration/Kalina cogeneration cycle, and obtained very low $\mathrm{f}_{\mathrm{k}}$ values for the condenser, high-pressure steam generator, and boiler, and concluded that selection of these components with higher quality and price can improve the overall performance of the cogeneration cycle. Mousavi and Mehrpooya [87] reported on a cascade absorption-compression refrigeration system, and after evaluation of $r_{k}$ and $f_{k}$, decided that the compressor and gas heat exchanger presented the best potential for optimization. Wang et al. [88] explored a novel cooling and power cycle and identified the vapor generator \#1 and solution heat exchanger as possibilities for optimization due to the high $\mathrm{r}_{\mathrm{k}}$ and low $\mathrm{f}_{\mathrm{k}}$. Souza et al. [71] proposed a cogeneration system based on the coupling of ORC and an absorption refrigeration system for a university building in Northeast Brazil and verified that further efficiency enhancement actions could be considered for the ORC steam generator.

Although exergoeconomics is as diagnosis tool and provides indications on where to concentrate improvement efforts, the decision-making process itself is beyond the scope of the method. Suggestions to improve the performance of the compact cogeneration unit include the consideration of a different heat exchanger (different materials and geometry, improving the heat exchange area) and pre-heating of input air. Also, other refrigerant fluids can be studied.

Regarding the design of the heat exchanger, investigations encompass the number and orientation of tube passes in the shell, longitudinal fins' length and thickness, and materials for shell, tube, and fins. Passive intensification of heat transfer in the form of baffles was studied by Andrzejczyk et al. [89], who obtained higher energy efficiency of the heat exchanger. Yan et al. [90] carried out numerical simulations with twisted tapes on the shell side of a shell and tube heat exchanger, verifying that the heat transfer coefficient increased with decreasing twist ratio and that the geometric and structural modifications improved design optimization. Considering that a significant component of a shell-tube heat exchanger is the tubes, Tahery et al. [91] studied different tube count, tube layout, and tube diameter at different baffle sections and obtained better heat transfer and lower exergy destruction rate for shell-tube heat exchangers with segmental baffles. Regarding materials, Khan et al. [92] demonstrated a significant effect on the thermal performance and observed that copper, aluminum, and aluminum 6063 presented a better thermal performance than steel AISI 4340. Because of the wide range of applicability of these heat exchangers, these improvements enhance domestic and commercial heat storage applications.

Although Riffat et al. [93] mention that volatile fluids will continue to be employed in cooling and power generation, new refrigerant fluids are required to optimize energy efficiency, increase safety, and decrease environmental impacts. The experimental results on the exergy behavior of R513A vs. R134a were discussed by Mota-Babiloni et al. [94], with higher exergy efficiency verified for R513A with the advantage that the system does not require retrofitting. Employing a mixture of nanomaterials with pure conventional working fluids (such as refrigerants) presents significant benefits, such as lower global warming potentials, zero ozone depletion potential, higher energy efficiency, lower power consumption, non-flammability, non-toxicity, heat transfer enhancement, and better tribological and rheological behavior [95]. Most research is still primarily focused on the use of R141b and R134a as working fluids [95], but the possibilities of using non-standard refrigerants must be considered (such as hydrofluoroolefins, either pure or mixed). Investigation and analysis of R463A as an alternative refrigerant to R404A was carried out successfully by Saengsikhiao et al. [96], while Życzkowski et al. [97] focused on R1234ze(E) due to the restrictions against the use of many refrigerants in the European Union since 2015. 


\subsection{Finals Remarks}

A detailed guide has been presented herein, which can be applied to other energy systems (even industrial processes). Special attention must be focused on the adequate selection of control volumes, establishment of the input and output locations for the energy flows, data collection (temperature, pressure, and flow), determination of other thermodynamic properties, correct application of first and second laws of thermodynamics, and finally, correct application of the SPECO method to define the costing equations.

Regarding the choice of prime mover, Reference [33] has already made a case for the utilization of ICE as the prime mover. ICE has several advantages related to drivability, durability, availability of equipment in different sizes, and easy maintenance. Also, ICE can operate with other fuels, such as biodiesel; however, the economic and environmental advantages are not straightforward. The emissions obtained by Reference [98] for biomass syngas were much lower than fossil diesel, and confirmed the potential to mitigate climate change, but Reference [99] obtained much higher emissions for soybean biodiesel than for fossil diesel.

Concerning the depletion of fossil fuels and the consequent uncertainties regarding the security of supply, the development and analysis of combined cooling and power systems has been attracting increasing interest in recent years [100-102]. The overarching purpose of combined cycles is the improvement of overall energy conversion efficiency in comparison with separate production. These combined systems can operate with low-grade heat sources and are very promising to supply power and refrigeration simultaneously. Traditional applications of electricity-cooling cogeneration systems include beverage and food industries, medical research facilities (storage of medicines and sensitive products), and marine transportation (marine engines are the largest category of ICE). Some of the advantages of compact electricity-cooling cogeneration units include: (1) possibility of meeting smaller-scale energy demands, such as for the tertiary sector (shopping centers, hospitals, hotels, supermarkets), (2) wide utilization in distributed generation schemes and outside large urban centers, (3) use of internal combustion engines, which are cheaper and easier to maintain than turbines, and (4) enables the use of renewable energy resources.

The advantages of utilizing exergoeconomics for the diagnosis of energy systems have been the overarching aim of this study, and demonstrated herein, taking into account the energy and exergy balances of system components. In this case, exergoeconomics enables the diagnosis of thermodynamic inefficiencies and identification of where exergy is destroyed within the system. Thus, it is clear which equipment needs to be prioritized regarding improvements in the project or even in the process as a whole. This demonstration is followed by a discussion on the method and productive structure.

Finally, when considering energy efficiency strategies and levels of greenhouse gases, electricity-cooling cogeneration systems are interesting options for the industrial sector but can also meet the cooling and electricity requirements of a district or a city. As of August 2020, the crisis precipitated by the COVID-19 pandemic has cascaded across socio-economic sectors [103]. The energy sector has been affected, which could potentially be averted by implementing stimulus plans to boost clean energy technologies [103] and energy efficiency schemes [104]. Pina et al. [105] mention that in the wake of the pandemic, countries must kickstart their economies while consolidating climate change commitments, and energy efficiency is a crucial pillar of the energy transition (along with renewable energy and energy storage). Due to the deceleration of most energy transition programs and considering the scarcity of studies on the impacts of COVID-19 on the electric sector, cogeneration systems can and must be part of energy efficiency solutions to enhance economic competitiveness, providing more affordable energy services, and reducing environmental impacts.

\section{Conclusions}

This study carried out an exergoeconomic assessment, using the SPECO method, for a compact electricity-cooling cogeneration unit (Otto internal combustion engine and a water-ammonia single-effect absorption chiller). A step-by-step, clear, and straightforward guide to the application 
of this exergy-based method was reported, with sufficient information to guarantee reproducibility and replicability.

With this work, it was possible to demonstrate the effectiveness of the SPECO method as a tool for diagnosing the inefficiencies of energy systems. From the combined analysis of exergoeconomic parameters $\left(r_{k}\right.$ and $\left.f_{k}\right)$, it is possible to prioritize interventions aimed at increasing energy use and reducing irreversibility and destruction of exergy.

Exergy destruction was higher in the internal combustion engine $(67.88 \%)$, followed by the steam generator $(14.46 \%)$. For the engine, this indicates that there are still margins for better utilization of its heat (e.g., heating of a secondary fluid). Regarding the steam generator, the high value was expected, as this component receives much more heat from the engine than it actually requires. Optimization efforts concentrate on the steam generator. Regarding the difference in relative costs for the absorber, this device could benefit from energy optimization as well.

The results of exergoeconomic assessments can aid in the promotion of more efficient electricity-cooling cogeneration units, especially in the aftermath of the COVID-19 crisis. Energy efficiency schemes, implemented through cogeneration systems, can play an essential role in the energy transition.

Future work by the authors includes considering the chemical exergy of the combustion products of the engine and exergoenvironmental assessment with the information provided through the application of the Life Cycle Assessment methodology.

Author Contributions: Conceptualization, A.d.S.M. and R.J.S.; Data curation, M.C.; Formal analysis, A.d.S.M., M.C. and R.J.S.; Methodology, A.d.S.M.; Resources, C.A.C.d.S.; Software, R.J.S.; Supervision, C.A.C.d.S.; Validation, Á.A.V.O.; Visualization, M.C. and Á.A.V.O.; Writing—original draft, A.d.S.M.; Writing—review and editing, M.C. and Á.A.V.O. All authors have read and agreed to the published version of the manuscript.

Funding: The authors wish to acknowledge the support of the National Council for Scientific and Technological Development (CNPq, Brazil), through a PhD. Scholarship, Universal project $n^{\circ} 402323 / 2016-5$, and Research Productivity grants $n^{\circ} 307394 / 2018-2$ and 309154/2019-7. Thanks are extended to IFPE for its financial support within the framework of Call 10/2019/Propesq, and to FACEPE/CNPq for the financial support regarding research project APQ-0151-3.05/14.

Conflicts of Interest: The authors declare no conflict of interest.

\section{References}

1. Arrieta, F.R.P.; Sodré, J.R.; Herrera, M.D.M.; Zárante, P.H.B. Exergoeconomic analysis of an absorption refrigeration and natural gas-fueled diesel power generator cogeneration system. J. Nat. Gas Sci. Eng. 2016, 36, 155-164. [CrossRef]

2. Kanbur, B.B.; Xiang, L.; Dubey, S.; Choo, F.H.; Duan, F. Thermoeconomic assessment of a micro cogeneration system with LNG cold utilization. Energy 2017, 129, 171-184. [CrossRef]

3. Gholizadeh, T.; Vajdi, M.; Rostamzadeh, H. Energy and exergy evaluation of a new bi-evaporator electricity/ cooling cogeneration system fueled by biogas. J. Clean. Prod. 2019, 233, 1494-1509. [CrossRef]

4. Pérez, A.A.D.; Palacio, J.C.E.; Venturini, O.J.; Reyes, A.M.M.; Orozco, D.J.R.; Lora, E.E.S.; Olmo, O.A.A. Thermodynamic and economic evaluation of reheat and regeneration alternatives in cogeneration systems of the Brazilian sugarcane and alcohol sector. Energy 2018, 152, 247-262. [CrossRef]

5. Pina, E.A.; Lozano, M.A.; Ramos, J.C.; Serra, L.M. Tackling thermal integration in the synthesis of polygeneration systems for buildings. Appl. Energy 2020, 269. [CrossRef]

6. Amar, J.A.; Lahoud, C.; Brouche, M. Decision-making strategy for cogeneration power systems integration in the Lebanese electricity grid. Energy Procedia 2017, 119, 801-805. [CrossRef]

7. Angrisani, G.; Akisawa, A.; Marrasso, E.; Roselli, C.; Sasso, M. Performance assessment of cogeneration and trigeneration systems for small scale applications. Energy Convers. Manag. 2016, 125, 194-208. [CrossRef]

8. Pérez-Iribarren, E.; González-Pino, I.; Azkorra-Larrinaga, Z.; Gómez-Arriarán, I. Optimal design and operation of thermal energy storage systems in micro-cogeneration plants. Appl. Energy 2020, 265. [CrossRef]

9. Freitas, L.A.; Magnani, F.S.; Hornsby, E.M. Robustness of electricity and chilled water supply systems subject to change technical and economic. IEEE Lat. Am. Trans. 2017, 15, 908-915. [CrossRef] 
10. Silva, H.C.N.; Ochoa, A.A.V.; Dutra, J.C.C.; Santos, C.A.C.; Costa, J.A.P. Modeling and simulation of cogeneration systems for buildings on a university campus in Northeast Brazil-A case study. Energy Convers. Manag. 2019, 186, 334-348. [CrossRef]

11. Uche, J.; Acevedo, L.; Círez, F.; Usón, S.; Martínez-Gracia, A.; Bayod-Rújula, A. Analysis of a domestic trigeneration scheme with hybrid renewable energy sources and desalting techniques. J. Clean. Prod. 2019, 212, 1409-1422. [CrossRef]

12. Cao, Y.; Zhang, G.; Li, D.; Wang, L.; Li, Z. Online energy management and heterogeneous task scheduling for smart communities with residential cogeneration and renewable energy. Energies 2018, 11, 2104. [CrossRef]

13. Kang, E.; Lee, E.; Ghorab, M.; Yang, L.; Entchev, E.; Lee, K.; Lyu, N. Investigation of energy and environmental potentials of a renewable trigeneration system in a residential application. Energies 2016, 9, 760. [CrossRef]

14. Xu, Z.Y.; Wang, R.Z. Comparison of absorption refrigeration cycles for efficient air-cooled solar cooling. Sol. Energy 2018, 172, 14-23. [CrossRef]

15. Dincer, I.; Ratlamwala, T.A.H. Integrated Absorption Refrigeration Systems: Comparative Energy and Exergy Analyses; Springer: Berlin/Heidelberg, Germany, 2016.

16. Bruckner, S.; Liu, S.; Miró, L.; Radspieler, M.; Cabeza, L.F.; Lavemann, E. Industrial waste heat recovery technologies: An economic analysis of heat transformation technologies. Appl. Energy 2015, 151, 157-167. [CrossRef]

17. Arora, R.C. Refrigeration and Air Conditioning; PHI Learning Pvt. Ltd.: New Delhi, India, 2012.

18. Sun, J.; Fu, L.; Zhang, S. A review of working fluids of absorption cycles. Renew. Sustain. Energy Rev. 2012, 16, 1899-1906. [CrossRef]

19. Li, Y.; Hu, R. Exergy-analysis based comparative study of absorption refrigeration and electric compression refrigeration in CCHP systems. Appl. Therm. Eng. 2016, 93, 1228-1237. [CrossRef]

20. Abdulrahim, H.K.; Darwish, M.A. Thermal desalination and air conditioning using absorption cycle. Desalin. Water Treat. 2015, 55, 3310-3329. [CrossRef]

21. Ochoa, A.A.V.; Dutra, J.C.C.; Henríquez, J.R.G.; Santos, C.A.C. Dynamic study of a single effect absorption chiller using the pair $\mathrm{LiBr} / \mathrm{H}_{2} \mathrm{O}$. Energy Convers. Manag. 2017, 136, 270-282. [CrossRef]

22. Ochoa, A.A.V.; Dutra, J.C.C.; Henríquez, J.R.G.; Dos Santos, C.A.C.; Rohatgi, J. The influence of the overall heat transfer coefficients in the dynamic behavior of a single effect absorption chiller using the pair $\mathrm{LiBr} / \mathrm{H}_{2} \mathrm{O}$. Energy Convers. Manag. 2017, 136, 270-282. [CrossRef]

23. Bouhal, T.; Agrouaz, Y.; El Rhafiki, T.; Kousksou, T.; Zeraouli, Y.; Jamil, A. Technical assessment, economic viability and investment risk analysis of solar heating/cooling systems in residential buildings in Morocco. Sol. Energy 2018, 170, 1043-1062. [CrossRef]

24. Ochoa, A.A.V.; Dutra, J.C.C.; Henríquez, J.R.G.; Santos, C.A.C.; Costa, J.A.P. Dynamic experimental analysis of a $\mathrm{LiBr} / \mathrm{H} 2 \mathrm{O}$ single effect absorption chiller with nominal capacity of $35 \mathrm{~kW}$ of cooling. Acta Technol. Sci. 2019, 41, 164-173. [CrossRef]

25. Carvalho, B.C.T.; Melo, C.T.M.C.B.; Romero, A.J.; Khanmohammadi, S.; Carvalho, M. Multicriteria optimization of renewable-based polygeneration system for tertiary sector buildings. Environ. Eng. Manag. J. 2019, 18, 2441-2453. [CrossRef]

26. Carvalho, M.; Delgado, D.B.M.; Chacartegui, R. Life cycle analysis as a decision criterion for the implementation of solar photovoltaic panels in as Northeast Brazil hospital. In Panagiotis Grammelis. (Org.). Energy, Transportation and Global Warming, 1st ed.; Springer International Publishing: Cham, Switzerland, 2016; Volume 1, pp. 295-314. [CrossRef]

27. Delgado, D.; Carvalho, M.; Junior, L.M.C.; Abrahão, R.; Chacartegui, R. Photovoltaic solar energy in the economic optimisation of energy supply and conversion. IET Renew. Power Gener. 2018, 12, 1263-1268. [CrossRef]

28. Kotas, T.J. The Exergy Method of Thermal Plant Analysis; Elsevier: Amsterdam, The Netherlands, 2013.

29. Bejan, A.; Tsatsaronis, G.; Moran, M.J. Thermal Design and Optimization; John Wiley \& Sons: Hoboken, NJ, USA, 1995.

30. Carvalho, M.; Silva, J.A. Second law assessment of a Hoffmann kiln for the red ceramics industry. J. Braz. Soc. Mech. Sci. Eng. 2018, 40, 525. [CrossRef]

31. Guerra, J.P.; Cardoso, F.H.; Kulay, A.N.L. Thermodynamic and environmental analysis of scaling up cogeneration units driven by sugarcane biomass to enhance power exports. Energies 2018, 11, 73. [CrossRef]

32. Silva, J.A.M.; Ávila Filho, S.; Carvalho, M. Assessment of energy and exergy efficiencies in steam generators. J. Braz. Soc. Mech. Sci. Eng. 2017, 39, 3217-3226. [CrossRef] 
33. Marques, A.S.; Carvalho, M.; Lourenço, A.B.; Dos Santos, C.A.C. Energy, exergy, and exergoeconomic evaluations of a micro-trigeneration system. J. Braz. Soc. Mech. Sci. Eng. 2020, 42, 324. [CrossRef]

34. Sharifi, M.A.R.; Khalilarya, S. Exergoeconomic evaluation and optimisation of a novel combined power and absorption-ejector refrigeration cycle driven by natural gas. Int. J. Exergy 2016, 19, 232-258. [CrossRef]

35. Hou, Z.; Wei, X.; Ma, X.; Meng, X. Exergoeconomic evaluation of waste heat power generation project employing organic Rankine cycle. J. Clean. Prod. 2020, 246, 119064. [CrossRef]

36. Kordlar, M.A.; Mahmoudi, S.M.S. Exergeoconomic analysis and optimization of a novel cogeneration system producing power and refrigeration. Energy Convers. Manag. 2017, 134, 208-220. [CrossRef]

37. Shu, G.; Wang, X.; Tian, H.; Liang, Y.; Liu, Y.; Liu, P. Analysis of an electricity-cooling cogeneration system for waste heat recovery of gaseous fuel engines. Sci. China Technol. Sci. 2015, 58, 37-46. [CrossRef]

38. Ochoa, G.V.; Peñaloza, C.A.; Forero, J.D. Thermo-economic assessment of a gas microturbine-absorption chiller trigeneration system under different compressor inlet air temperatures. Energies 2019, 12, 4643. [CrossRef]

39. Baniasadi, E.; Toghyani, S.; Afshari, E. Exergetic and exergoeconomic evaluation of a trigeneration system based on natural gas-PEM fuel cell. Int. J. Hydrogen Energy 2017, 42, 5327-5339. [CrossRef]

40. Baghernejad, A.; Yaghoubi, M.; Jafarpur, K. Exergoeconomic comparison of three novel trigeneration systems using SOFC, biomass and solar energies. Appl. Therm. Eng. 2016, 104, 534-555. [CrossRef]

41. Yang, K.; Zhu, N.; Ding, Y.; Chang, C.; Yuan, T. Thermoeconomic analysis of an integrated combined cooling heating and power system with biomass gasification. Energy Convers. Manag. 2018, 148, 1409-1425. [CrossRef]

42. Liu, Z.; Liu, Z.; Yang, X.; Zhai, H.; Yang, X. Advanced exergy and exergoeconomic analysis of a novel liquid carbon dioxide energy storage system. Energy Convers. Manag. 2020, 205, 112391. [CrossRef]

43. Cavalcanti, E.J.; Carvalho, M.; Azevedo, J.L. Exergoenvironmental results of a eucalyptus biomass-fired power plant. Energy 2019, 189, 116188. [CrossRef]

44. Wang, L.; Yang, Z.; Sharma, S.; Mian, A.; Lin, T.E.; Tsatsaronis, G.; Maréchal, F.; Yang, Y. A review of evaluation, optimization and synthesis of energy systems: Methodology and application to thermal power plants. Energies 2019, 12, 73. [CrossRef]

45. Lazzaretto, A.; Tsatsaronis, G. SPECO: A systematic and general methodology for calculating efficiencies and costs in thermal systems. Energy 2006, 31, 1257-1289. [CrossRef]

46. Mazloum, Y.; Sayah, H.; Nemer, M. Exergy analysis and exergoeconomic optimization of a constant-pressure adiabatic compressed air energy storage system. J. Energy Storage 2017, 14, 192-202. [CrossRef]

47. Kerdan, I.G.; Raslan, R.; Ruyssevelt, P.; Gálvez, D.M. An exergoeconomic-based parametric study to examine the effects of active and passive energy retrofit strategies for buildings. Energy Build. 2016, 133, 155-171. [CrossRef]

48. Fathia, H.; Tahar, K.; Ali, B.Y.; Ammar, B.B. Exergoeconomic optimization of a double effect desalination unit used in an industrial steam power plant. Desalination 2018, 438, 63-82. [CrossRef]

49. Mahmoudi, S.M.; Salehi, S.; Yari, M.; Rosen, M.A. Exergoeconomic performance comparison and optimization of single-stage absorption heat transformers. Energies 2017, 10, 532. [CrossRef]

50. Zhao, Y.; Wang, J.; Cao, L.; Wang, Y. Comprehensive analysis and parametric optimization of a CCP (Combined cooling and power) system driven by geothermal source. Energy 2016, 97, 470-487. [CrossRef]

51. Wang, J.; Wang, J.; Zhao, P.; Dai, Y. Thermodynamic analysis of a new combined cooling and power system using ammonia-water mixture. Energy Convers. Manag. 2016, 117, 335-342. [CrossRef]

52. Ghaebi, H.; Parikhani, T.; Rostamzadeh, H.; Farhang, B. Thermodynamic and thermoeconomic analysis and optimization of a novel combined cooling and power (CCP) cycle by integrating of ejector refrigeration and Kalina cycles. Energy 2017, 139, 262-276. [CrossRef]

53. Cao, L.; Wang, J.; Wang, H.; Zhao, P.; Dai, Y. Thermodynamic analysis of a Kalina-based combined cooling and power cycle driven by low-grade heat source. Appl. Therm. Eng. 2017, 111, 8-19. [CrossRef]

54. Seyfouri, Z.; Ameri, M.; Mehrabian, M.A. Exergo-economic analysis of a low-temperature geothermal-fed combined cooling and power system. Appl. Therm. Eng. 2018, 145, 528-540. [CrossRef]

55. Parikhani, T.; Ghaebi, H.; Rostamzadeh, H. A novel geothermal combined cooling and power cycle based on the absorption power cycle: Energy, exergy and exergoeconomic analysis. Energy 2018, 153, 265-277. [CrossRef] 
56. Tian, M.W.; Parikhani, T.; Jermsittiparsert, K.; Ashraf, M.A. Exergoeconomic optimization of a new double-flash geothermal-based combined cooling and power (CCP) system at two different cooling temperatures assisted by boosters. J. Clean. Prod. 2020, 120921. [CrossRef]

57. Ayou, D.S.; Eveloy, V. Energy, exergy and exergoeconomic analysis of an ultra low-grade heat-driven ammonia-water combined absorption power-cooling cycle for district space cooling, sub-zero refrigeration, power and LNG regasification. Energy Convers. Manag. 2020, 213, 112790. [CrossRef]

58. Xia, J.; Guo, Y.; Li, Y.; Wang, J.; Zhao, P.; Dai, Y. Thermodynamic analysis and comparison study of two novel combined cooling and power systems with separators using CO2-based mixture for low grade heat source recovery. Energy Convers. Manag. 2020, 215, 112918. [CrossRef]

59. Engineering Equation Solver. Software. 2019. Available online: http://fchartsoftware.com/ees/ (accessed on 2 September 2019).

60. Herold, K.E.; Radermarcher, R.; Klein, S.A. Absorption Chillers and Heat Pumps; CRC Press: Boca Raton, FL, USA, 2016.

61. Muñoz, M.; Valero, A. Thermoeconomic analysis of a cogeneration plant. In Thermodynamic Analysis and Improvement of Energy Systems; Ruixian, C., Moran, M.J., Eds.; Pergamon Press: Oxford, UK, 1989; pp. $210-219$.

62. Horlock, J.H. Cogeneration-combined heat and power (CHP). In Thermodynamics and Economics; Pergamon Press: Oxford, UK, 1987.

63. Petrakopoulou, F.; Tsatsaronis, G.; Morousk, T.; Carassai, A. Advanced exergoeconomic analysis applied to a complex energy conversion system. J. Eng. Gas Turbines Power 2012, 134, 031801. [CrossRef]

64. Tsatsaronis, G. Advanced exergy-based methods. CRC Handbook of Thermal Engineering; CRC Press LLC: Boca Raton, FL, USA, 2017; p. 107.

65. Abusoglu, A.; Kanoglu, M. Exergoeconomic analysis and optimization of combined heat and power production: A review. Renew. Sustain. Energy Rev. 2009, 13, 2295-2308. [CrossRef]

66. Manesh, M.H.K.; Amidpour, M.; Farhadi, A.; Salehi, G.R. Evaluation of coupling desalination with PWR nuclear power plant with pinch, exergy and thermoeconomic analysis. In Proceedings of the 16th International Conference on Nuclear Engineering, Orlando, FL, USA, 11-15 May 2008; American Society of Mechanical Engineers: New York, NY, USA, 2009. [CrossRef]

67. Daghigh, R.; Shafieian, A. An investigation of heat recovery of submarine diesel engines for combined cooling, heating and power systems. Energy Convers. Manag. 2016, 108, 50-59. [CrossRef]

68. Alcântara, S.C.S.; Ochoa, A.A.V.; Costa, J.A.P.; Michima, P.S.A.; Silva, H.C.N. Natural gas based trigeneration system proposal to an ice cream factory: An energetic and economic assessment. Energy Convers. Manag. 2019, 197, 111860. [CrossRef]

69. Vittorini, D.; Di Battista, D.; Cipollone, R. Engine oil warm-up through heat recovery on exhaust gases-Emissions reduction assessment during homologation cycles. Therm. Sci. Eng. Prog. 2018, 5, 412-421. [CrossRef]

70. Valencia, G.; Fontalvo, A.; Cárdenas, Y.; Duarte, J.; Isaza, C. Energy and exergy analysis of different exhaust waste heat recovery systems for natural gas engine based on ORC. Energies 2019, 12, 2378. [CrossRef]

71. Souza, R.J.; Santos, C.A.C.; Ochoa, A.A.V.; Marques, A.S.; Neto, J.L.M.; Michima, P.S.A. Proposal and 3E (energy, exergy, and exergoeconomic) assessment of a cogeneration system using an organic Rankine cycle and an Absorption Refrigeration System in the Northeast Brazil: Thermodynamic investigation of a facility case study. Energy Convers. Manag. 2020, 217, 113002. [CrossRef]

72. Xu, Z.Y.; Wang, R.Z.; Yang, C. Perspectives for low-temperature waste heat recovery. Energy 2019, 176, 1037-1043. [CrossRef]

73. Xu, Y.; Jiang, N.; Pan, F.; Wang, Q.; Gao, Z.; Chen, G. Comparative study on two low-grade heat driven absorption-compression refrigeration cycles based on energy, exergy, economic and environmental (4E) analyses. Energy Convers. Manag. 2017, 133, 535-547. [CrossRef]

74. Mohammadi, A.; Ahmadi, M.H.; Bidi, M.; Joda, F.; Valero, A.; Uson, S. Exergy analysis of a Combined Cooling, Heating and Power system integrated with wind turbine and compressed air energy storage system. Energy Convers. Manag. 2017, 131, 69-78. [CrossRef]

75. Bagheri, B.S.; Shirmohammadi, R.; Mahmoudi, S.M.S.; Rosen, M.A. Optimization and comprehensive exergy-based analyses of a parallel flow double-effect water-lithium bromide absorption refrigeration system. Appl. Therm. Eng. 2019, 152, 643-653. [CrossRef] 
76. Mohtaram, S.; Omidi, M.; Lin, J.; Sun, H.; Chen, W. Exergy analysis of a multi mixture working fluid absorption refrigeration cycle. Case Stud. Therm. Eng. 2019, 15, 100540. [CrossRef]

77. Schroeder, D.; Hegner, R.; Güngör, A.; Atakan, B. Exergoeconomic analysis of an HCCI engine polygeneration process. Energy Convers. Manag. 2020, 203, 112085. [CrossRef]

78. Razmara, M.; Bidarvatan, M.; Shahbakhti, M.; Robinett, R.D., III. Optimal exergy-based control of internal combustion engines. Appl. Energy 2016, 183, 1389-1403. [CrossRef]

79. Li, Y.; Jia, M.; Kokjohn, S.L.; Chang, Y.; Reitz, R.D. Comprehensive analysis of exergy destruction sources in different engine combustion regimes. Energy 2018, 149, 697-708. [CrossRef]

80. Song, J.; Song, H.H. Analytical Approach to the Exergy Destruction and the Simple Expansion Work Potential in the Constant Internal Energy and Volume Combustion Process. Energies 2020, 13, 395. [CrossRef]

81. Shokati, N.; Khanahmadzadeh, S. The effect of different combinations of ammonia-water Rankine and absorption refrigeration cycles on the exergoeconomic performance of the cogeneration cycle. Appl. Therm. Eng. 2018, 141, 1141-1160. [CrossRef]

82. Shokati, N.; Ranjbar, F.; Yari, M. A comprehensive exergoeconomic analysis of absorption power and cooling cogeneration cycles based on Kalina, part 1: Simulation. Energy Convers. Manag. 2018, 158, 437-459. [CrossRef]

83. Cavalcanti, E.J.C. Exergoeconomic and exergoenvironmental analyses of an integrated solar combined cycle system. Renew. Sustain. Energy Rev. 2017, 67, 507-519. [CrossRef]

84. Cavalcanti, E.J.; Souza, G.F.D.; Lima, M.S. Evaluation of cogeneration plant with steam and electricity production based on thermoeconomic and exergoenvironmental analyses. Int. J. Exergy 2018, 25, $203-223$. [CrossRef]

85. Wu, C.; Wang, S.S.; Feng, X.J.; Li, J. Energy, exergy and exergoeconomic analyses of a combined supercritical CO2 recompression Brayton/absorption refrigeration cycle. Energy Convers. Manag. 2017, 148, 360-377. [CrossRef]

86. Rashidi, J.; Yoo, C.K. Exergetic and exergoeconomic studies of two highly efficient power-cooling cogeneration systems based on the Kalina and absorption refrigeration cycles. Appl. Therm. Eng. 2017, 124, 1023-1037. [CrossRef]

87. Mousavi, S.A.; Mehrpooya, M. A comprehensive exergy-based evaluation on cascade absorption-compression refrigeration system for low temperature applications-exergy, exergoeconomic, and exergoenvironmental assessments. J. Clean. Prod. 2020, 246, 119005. [CrossRef]

88. Wang, Y.; Chen, T.; Liang, Y.; Sun, H.; Zhu, Y. A novel cooling and power cycle based on the absorption power cycle and booster-assisted ejector refrigeration cycle driven by a low-grade heat source: Energy, exergy and exergoeconomic analysis. Energy Convers. Manag. 2020, 204, 112321. [CrossRef]

89. Andrzejczyk, R.; Muszynski, T.; Gosz, M. Experimental investigations on heat transfer enhancement in shell coil heat exchanger with variable baffles geometry. Chem. Eng. Process. Process Intensif. 2018, 132, 114-126. [CrossRef]

90. Yang, D.; Khan, T.S.; Al-Hajri, E.; Ayub, Z.H.; Ayub, A.H. Geometric optimization of shell and tube heat exchanger with interstitial twisted tapes outside the tubes applying CFD techniques. Appl. Therm. Eng. 2019, 152, 559-572. [CrossRef]

91. Tahery, A.A.; Khalilarya, S.; Jafarmadar, S. Effectively designed NTW shell-tube heat exchangers with segmental baffles using flow hydraulic network method. Appl. Therm. Eng. 2017, 120, 635-644. [CrossRef]

92. Khan, Z.; Khan, Z.; Tabeshf, K. Parametric investigations to enhance thermal performance of paraffin through a novel geometrical configuration of shell and tube latent thermal storage system. Energy Convers. Manag. 2016, 127, 355-365. [CrossRef]

93. Riffat, S.; Aydin, D.; Powell, R.; Yuan, Y. Overview of working fluids and sustainable heating, cooling and power generation technologies. Int. J. Low Carbon Technol. 2017, 12, 369-382. [CrossRef]

94. Mota-Babiloni, A.; Belman-Flores, J.M.; Makhnatch, P.; Navarro-Esbrí, J.; Barroso-Maldonado, J.M. Experimental exergy analysis of R513A to replace R134a in a small capacity refrigeration system. Energy 2018, 162, 99-110. [CrossRef]

95. Gil, B.; Kasperski, J. Efficiency evaluation of the ejector cooling cycle using a new generation of $\mathrm{HFO} / \mathrm{HCFO}$ refrigerant as a R134a replacement. Energies 2018, 11, 2136. [CrossRef]

96. Saengsikhiao, P.; Taweekun, J.; Maliwan, K.; Sae-ung, S.; Theppaya, T. Investigation and Analysis of R463A as an Alternative Refrigerant to R404A with Lower Global Warming Potential. Energies 2020, 13, 1514. [CrossRef] 
97. Życzkowski, P.; Borowski, M.; Łuczak, R.; Kuczera, Z.; Ptaszyński, B. Functional Equations for Calculating the Properties of Low-GWP R1234ze (E) Refrigerant. Energies 2020, 13, 3052. [CrossRef]

98. Melo, F.M.; Silvestre, A.; Carvalho, M. Carbon footprints associated with electricity generation from biomass syngas and diesel. Environ. Eng. Manag. J. EEMJ 2019, 18, 1391-1397.

99. Carvalho, M.; Silva, E.S.; Andersen, S.L.; Abrahão, R. Life cycle assessment of the transesterification double step process for biodiesel production from refined soybean oil in Brazil. Environ. Sci. Pollut. Res. 2016, 23, 11025-11033. [CrossRef]

100. Ochoa, A.A.; Dutra, J.C.C.; Henríquez, J.R.; Santos, C.A.C. Techno-economic and Exergoeconomic Analysis of a micro cogeneration system for a residential use. Acta Sci. Technol. 2016, 38, 327-338. [CrossRef]

101. Cavalcante, A.W.A.; Santos, C.A.C.; Ochoa, A.A.V. Thermodynamic analysis of an energy high performance systems. IEEE Lat. Am. Trans. 2017, 15, 454-461. [CrossRef]

102. Cavalcanti, E.J.; Carvalho, M.; Silva, D.R. Energy, exergy and exergoenvironmental analyses of a sugarcane bagasse power cogeneration system. Energy Convers. Manag. 2020, 222, 113232. [CrossRef] [PubMed]

103. Lenzen, M.; Li, M.; Malik, A.; Pomponi, F.; Sun, Y.Y.; Wiedmann, T.; Gómez-Paredes, J. Global socio-economic losses and environmental gains from the Coronavirus pandemic. PLoS ONE 2020, 15, e0235654. [CrossRef] [PubMed]

104. Carvalho, C.; Delgado, D.B.M.; Lima, K.M.; Cancela, M.C.; Siqueira, C.A.S.; Souza, D.L.B. Effects of the covid-19 pandemic on the Brazilian electricity consumption patterns. Int. J. Energy Res. 2020, e5877. [CrossRef]

105. Pina, E.A.; Serra, L.M.; Lozano, M.A.; Hernández, A.; Lázaro, A. Comparative analysis and design of a solar-based parabolic trough-orc cogeneration plant for a commercial center. Energies 2020, 13, 4807. [CrossRef]

Publisher's Note: MDPI stays neutral with regard to jurisdictional claims in published maps and institutional affiliations. 